\title{
Road traffic injuries and substance use among emergency department patients in the Dominican Republic and Peru
}

\author{
Cheryl J. Cherpitel, ${ }^{1}$ Jane Witbrodt, ${ }^{1}$ Yu Ye, ${ }^{1}$ Maristela G. Monteiro, ${ }^{2}$ Hernán Málaga, ${ }^{3}$ Jeannette Báez, ${ }^{4}$ \\ and Marisela Ponce de León Valdés ${ }^{5}$
}

Suggested citation Cherpitel CJ, Witbrodt J, Ye Y, Monteiro MG, Málaga H, Báez J, et al. Road traffic injuries and substance use among emergency department patients in the Dominican Republic and Peru. Rev Panam Salud Publica. 2021;45:e31.

https://doi.org/10.26633/RPSP.2021.31

ABSTRACT Objective. To report demographic and substance use characteristics and risk of road traffic injury (RTI) from alcohol use, cannabis use, and combined use in a sample of emergency department patients from two countries in Latin America and the Caribbean.

Methods. A cross-sectional study in which patients 18 years and older admitted within six hours of suffering an RTI to one emergency department in Santa Domingo, Dominican Republic $(n=501)$ and in Lima, Peru $(n=431)$ were interviewed. Case-crossover analysis, based on self-reported use prior to the RTI, was used to analyze risk from alcohol, cannabis, and co-use.

Results. Overall, $15.3 \%$ reported alcohol use prior to the event and $2.5 \%$ cannabis use. Drivers using alcohol only were over twice as likely to have an $\mathrm{RTI}(\mathrm{OR}=2.46, p<0.001)$, and nearly eight times more likely if using both alcohol and cannabis $(\mathrm{OR}=6.89, p<0.01)$, but risk was not elevated for cannabis alone. Significant differences were not found for passengers or pedestrians.

Conclusions. Risk of RTI for drivers in these two samples is significantly elevated from alcohol use, and more so for co-use with cannabis. Differences between the two countries underscore the need for similar data from the region to determine risk of RTI from substance use, including risk for passengers and pedestrians. Data suggest that alcohol contributes significantly to the burden of RTI, which calls for more stringent enforcement of alcohol control policy related to drink driving in the region.

Keywords $\quad$ Accidents, traffic; safety; driving under the influence; alcohol drinking; illicit drugs; emergency service, hospital; Latin America; Caribbean region.

Road traffic injuries (RTI) were responsible for 1.35 million fatalities worldwide in 2016, up from 1.2 million in 2013, despite the fact that the death rate relative to the world's population remained constant during this time (1). They are the leading cause of death among those aged 5-29 years. RTI fatalities are more than three times higher in low-income compared with high-income countries. Between 2013 and 2016, no reduction in RTI deaths was observed in low-income countries while some reductions were apparent in middle- and high-income countries (1). In recognition of the toll of RTIs and deaths and the

\footnotetext{
Alcohol Research Group, Emeryville, Calif., United States of America $\triangle$ Cheryl J. Cherpitel, ccherpitel@arg.org

2 Pan American Health Organization, Washington, D.C., United States of America

3 Ricardo Palma University, Lima, Peru
}

\footnotetext{
4 National Center of Investigations in Maternal Child Health, Santo Domingo, Dominican Republic

5 Inter-American Development Bank, Washington, D.C., United States of America
} 
role of substance use, the United Nations General Assembly adopted a resolution in 2010 (2) leading to establishment of the Decade of Action for Road Safety (2011-2020) and adoption of the Agenda for Sustainable Development that set the goal of reducing RTIs and deaths by $50 \%$ by 2020 , with alcohol and drug use while driving as key targets (3).

Alcohol consumption in Latin America and the Caribbean (LAC) is one of the highest and most hazardous to health worldwide $(4,5)$, with a significant impact on injuries including RTIs (6). Risk was found to be five times greater for those reporting drinking within six hours prior to an RTI among emergency department (ED) patients in the LAC region, and increased by $13 \%$ for each drink consumed (7). Less is known about risk of RTIs associated with substance use other than alcohol, or combined use with alcohol, although psychoactive drugs affect reaction time and other driving skills. Use of psychoactive substances is increasing globally, with cannabis most commonly used after alcohol and the drug most frequently used with alcohol (8-10). A review of epidemiological studies found a significant risk of RTI from cannabis (11) ranging from 1.2 (12) to 2.66 (13), while another systematic review found a risk of 2.84 (14). Greater impairment has been found when alcohol is combined with cannabis than when either substance is used alone (15-20). The European Monitoring Centre for Drugs and Drug Addiction assigned risk levels of being seriously injured or killed as a driver as a slightly increased risk for cannabis or alcohol $<0.05 \mathrm{mg} \%$; a moderately increased risk for cocaine, opiates, benzodiazepines, or alcohol between $0.05-0.08 \mathrm{mg} \%$; and a highly increased risk for amphetamines, multiple drugs, or alcohol $>0.08 \mathrm{mg} \%$ (21).

Evidence on the contribution of alcohol and other substance use to RTI is more abundant in higher-income than in lowerincome countries, where the literature is scant and sound epidemiological studies are lacking. Additionally, many studies of RTI do not distinguish between drivers and passengers, or pedestrians, who are particularly vulnerable in lower-income countries where they account for up to $50 \%$ of road traffic fatalities (1), but are seldom included in these studies. The objectives of this study are to report demographic and substance use characteristics and risk of RTI from alcohol use, cannabis use, and combined use in a sample of ED patients from two countries in the LAC region. Findings will help inform intervention and prevention strategies to reduce substance-related harm from RTIs in this region.

\section{MATERIALS AND METHODS}

The Multi-Site Collaborative Study on Alcohol, Drug Use, and Road Traffic Injuries in Emergency Departments is a cross-sectional study which was implemented in two hospitals: Dr. Darío Contreras Traumatology Hospital in Santo Domingo, Dominican Republic (from October 2018 to January 2019) and José Casimiro Ulloa Emergency Hospital in Lima, Peru (December 2018 to June 2019). Study protocols follow those previously used in ED studies in the International Collaborative Alcohol and Injury Study (ICAIS) (22). All sampled consecutive patients aged 18 years and above admitted to the ED within six hours of an RTI as either a driver, passenger, or pedestrian were eligible for the study, which included a blood alcohol concentration (BAC) estimate (using the AlcoMate breathalyzer), a saliva sample (using the Alere Oratect which determines use of cannabis, amphetamines, cocaine, methamphetamines, opiates, and phencyclidine), and an interview-administered, 35-minute, computerized questionnaire.

The questionnaire included items eliciting information on the RTI (including whether the patient was the driver, passenger, or pedestrian and type of vehicle(s) involved), drinking and drug use by class within six hours prior to the event, amount of alcohol/cannabis consumed, whether the patient felt intoxicated/ impaired at the time, whether the patient felt the RTI would have happened if he had not been drinking/using (causal attribution), drinking and drug use during the same six-hour period for each of the seven days prior to the event and amount of alcohol/cannabis used during each time period, frequency of usual drinking and amount consumed, frequency of higher consumption times (12+, 5-11, and 1-4 drinks on an occasion), frequency of usual drug use, and demographic characteristics.

\section{Data analysis}

Risk of RTI from alcohol or drug use was calculated using case-crossover analysis $(23,24)$ in which each patient's substance use in the six hours preceding the injury is compared with use in the same six-hour period for each of the seven days (seven control periods) preceding the day of injury. This method controls for stable risk factors such as gender, age, and usual substance use patterns. Substance use data were only obtained for those control periods for which the patient's activity (driver, passenger, pedestrian) was the same as the activity at the time of the RTI. Control periods matched by activity for each patient were then merged and an average taken of substance use over all matched periods. Those patients for whom a match was not obtained for any of the seven control periods were asked the last time they had been engaged in the same activity they were engaged in at the time of the RTI, spanning a period of one hour before to one hour after the time of the RTI. The majority of patients matched on at least one of the seven days and analysis including those patients who did not match on one of these control periods was not significantly different than analyses including only those on whom a match was achieved. Consequently, data reported here only include those on whom a seven-day match was obtained.

Conditional logistic regression was used to estimate odds ratios (OR) and 95\% confidence intervals (CI) for risk of injury, separately for alcohol use, cannabis use, and co-use within six hours prior to the RTI for the whole sample and by RTI type (driver, passenger, pedestrian). Both additive and multiplicative interactions (25) between alcohol and cannabis use were estimated. For additive interaction, Relative Excess Risk due to Interaction (RERI) assessed whether the joint effect from combined use was larger than the expected added effects from use of each alone. Multiplicative interaction was assessed by entering the interaction term between alcohol and cannabis use in the conditional logistic regression.

All patients were approached by a trained interviewer to provide informed consent to participate in the study prior to obtaining breath and saliva samples and interviewing the patient. Data were identified by a study ID number only, prohibiting any linkage to the patient. Both studies were reviewed by the appropriate national ethics committee or institutional 
TABLE 1. Demographic characteristics of the emergency department samples

\begin{tabular}{|c|c|c|c|}
\hline & $\begin{array}{c}\text { Dominican } \\
\text { Republic } \\
(n=501) \\
\%\end{array}$ & $\begin{array}{c}\text { Peru } \\
(n=431) \\
\%\end{array}$ & $\begin{array}{c}\text { Combined } \\
\text { samples } \\
(n=932) \\
\%\end{array}$ \\
\hline Male & 85.5 & 61.4 & $74.4^{\star * \star}$ \\
\hline Age $<30$ years & 58.0 & 44.2 & $51.6^{\star \star \star}$ \\
\hline \multicolumn{4}{|l|}{ Marital status } \\
\hline Married/partnered & 48.6 & 50.4 & 49.4 \\
\hline Single, never married & 40.9 & 34.8 & 38.0 \\
\hline Widowed/separated/divorced & 10.6 & 14.9 & 12.6 \\
\hline \multicolumn{4}{|l|}{ Education } \\
\hline Less than high school & 45.2 & 20.8 & $34.1^{* * *}$ \\
\hline High school completion & 38.8 & 22.0 & 31.1 \\
\hline Any college/tech school & 16.1 & 57.2 & 34.8 \\
\hline \multicolumn{4}{|l|}{ Employment status } \\
\hline $\begin{array}{l}\text { Working } 30 \text { hours or more/ } \\
\text { week }\end{array}$ & 66.3 & 70.8 & 68.3 \\
\hline \multicolumn{4}{|l|}{ Road traffic injury type } \\
\hline Driver & 74.1 & 42.2 & $59.3^{* * *}$ \\
\hline Passenger & 18.6 & 32.7 & 25.1 \\
\hline Pedestrian & 7.4 & 25.1 & 15.6 \\
\hline \multicolumn{4}{|l|}{ Vehicle type (excl. pedestrians) } \\
\hline Car/truck & 11.5 & 32.5 & $20.1^{* * *}$ \\
\hline Bus & 0.6 & 10.8 & 4.8 \\
\hline Motorcycle or scooter/moped & 86.4 & 43.0 & 68.6 \\
\hline Bicycle & 0.4 & 11.1 & 4.8 \\
\hline Other & 1.1 & 2.5 & 1.7 \\
\hline \multicolumn{4}{|l|}{$\begin{array}{l}\text { Were you using a ... (excl. } \\
\text { pedestrians) }\end{array}$} \\
\hline Seatbelt & 5.4 & 10.0 & $7.3^{\star \star \star}$ \\
\hline Helmet & 19.9 & 39.8 & 28.1 \\
\hline Nothing & 74.7 & 50.2 & 64.6 \\
\hline
\end{tabular}

$* * * p<0.001$, Chi-square test
Source: Prepared by the authors from the study results

review board, as well as the Pan American Health Organization (PAHO) Ethics Review Committee.

\section{RESULTS}

Completion rates averaged $88.3 \%$, resulting in 501 completed interviews in the Dominican Republic and 431 in Peru. Reasons for non-interviews included refusing $(7.6 \%)$, incapacitation $(1.9 \%)$, leaving prior to completing the interview $(0.4 \%)$, language barriers $(0.6 \%)$, and other reasons $(1.9 \%)$. Patients who were too severely injured to be approached in the ED were followed into the hospital and interviewed once their condition had stabilized.

The majority of patients were male $(74.4 \%),<30$ years $(51.6 \%)$, married $(49.4 \%)$, had at least a high school education $(65.9 \%)$, and were employed (68.3\%) (Table 1). Patients were more likely to be drivers, to be on motorcycles/scooters, and not to be wearing a helmet. Significance differences were found between the two sites, with those in the Dominican Republic more likely to be male, younger, and less educated than those in Peru (all $p<0.001$ ). Nearly three-quarters of patients in the
Dominican Republic were drivers $(74.1 \%)$, compared with less than half in Peru $(42.2 \%)(p<0.001)$. Excluding pedestrians, $86.4 \%$ of RTIs involved a motorcycle/scooter in the Dominican Republic, compared with $43 \%$ in Peru; while in Peru, $32.5 \%$ of patients were in a car, compared with $11.5 \%$ in the Dominican Republic $(p<0.001)$. While patients in the Dominican Republic were more likely to be on a motorcycle/scooter than those in Peru, they were less likely to be wearing a helmet $(19.9 \%$ vs. $39.8 \%)(p<0.001)$.

Overall, $17.8 \%$ of patients were positive for alcohol based on the breathalyzer, and $11.2 \%$ were over $0.08 \mathrm{mg} \%$ (Table 2 ). The legal level of BAC in both countries is 0.05 . Of the patients, $15.3 \%$ reported drinking within 6 hours prior to the RTI. Although no difference was found between the two sites in the proportion of positive BAC, patients in the Dominican Republic were more likely to report drinking prior to the event $(19.3 \%)$ than those in Peru $(10.2 \%)(p<0.001)$.

Among those drinking in the six hours preceding the RTI, close to half reported more than eight drinks (49.6\%), with 78\% of these patients reporting being at least a little intoxicated at the time and $69.1 \%$ believing or were unsure whether the RTI would have occurred if they had not been drinking (causal attribution). Of those attributing a causal association, $80 \%$ reported being intoxicated at the time (not shown). Among current drinkers, $28.7 \%$ reported five or more drinks on an occasion at least weekly.

Those in the Dominican Republic were more likely to report eight or more drinks prior to injury (52.3\%) than those in Peru $(41.9 \%)$, and were more likely to report being intoxicated $(81.2 \%$ vs. $69.4 \%$ ); however, differences were not significant although those in the Dominican Republic were significantly more likely to report a causal association of their injury with drinking $(87.1 \%$ vs. $47.4 \%, p<0.001)$. Those in the Dominican Republic were also significantly more likely to report frequent heavy drinking (five or more drinks on an occasion at least weekly) $(32.2 \%)$ compared with those in Peru $(12.3 \%)(p<0.001)$.

Of the sample, $12.3 \%$ tested positive for at least one drug, with patients in the Dominican Republic almost twice as likely to be positive $(17.9 \%)$ than those in Peru $(9.6 \%)(p<0.001)$. Cannabis was the most frequently detected drug (11.8\%), and those in the Dominican Republic were significantly more likely to be positive $(15.7 \%)$ compared with those in Peru $(6.6 \%)$ $(p<0.001)$. The legal level of cannabis in both countries is zero. Those in the Dominican Republic were also more likely to be positive for opiates $(2.1 \%)$ than those in Peru $(0.3 \%)(p<0.05)$. All drugs other than cannabis were detected in relatively small percentages.

Among patients, 3.5\% reported drug use prior to injury with $2.5 \%$ reporting cannabis use. Most cannabis users reported one to several puffs from a joint (62\%) and the remainder from one to almost two joints. Among those reporting any drug use prior to injury, $58.3 \%$ reported being at least a little impaired at the time of the RTI and $66.7 \%$ believed or were unsure whether the RTI would have occurred if they had not been using drugs. While $75 \%$ of those in the Dominican Republic reported being at least a little impaired compared with $25 \%$ in Peru, they were less likely to attribute a causal association of their injury with using (62.5\% vs. $75 \%)$, although differences were not significant due to small numbers of patients reporting drug use prior to injury. The majority of cannabis users reported usual use less than once a week (55.6\%), with those in the Dominican Republic 
TABLE 2. Substance use characteristics of the emergency department samples

\begin{tabular}{|c|c|c|c|}
\hline & $\begin{array}{c}\text { Dominican Republic } \\
(n=501) \\
\%\end{array}$ & $\begin{array}{c}\text { Peru } \\
(n=431) \\
\%\end{array}$ & $\begin{array}{c}\text { Combined samples } \\
\qquad \begin{array}{c}(n=932) \\
\%\end{array}\end{array}$ \\
\hline \multicolumn{4}{|l|}{ Alcohol use } \\
\hline$\overline{\mathrm{BAC}}$ (positive) ${ }^{\mathrm{a}}$ & 18.8 & 16.6 & 17.8 \\
\hline $\mathrm{BAC} \geq 0.8$ & 12.6 & 9.5 & 11.2 \\
\hline Self-report alcohol use within 6 hours prior to injury & 19.3 & 10.2 & $15.3^{\star \star \star}$ \\
\hline \multicolumn{4}{|l|}{ Number of drinks among 6-hour drinkers } \\
\hline$\leq 3.0$ drinks & 29.1 & 38.7 & 31.6 \\
\hline $3.1-8.0$ drinks & 18.6 & 19.4 & 18.8 \\
\hline$>8$ drinks & 52.3 & 41.9 & 49.6 \\
\hline \multicolumn{4}{|c|}{ Feeling intoxicated at the time among those drinking within 6 hours prior to injury } \\
\hline Not intoxicated & 18.8 & 30.6 & 22.0 \\
\hline A little intoxicated & 39.6 & 38.9 & 39.4 \\
\hline Somewhat intoxicated & 31.3 & 25.0 & 29.5 \\
\hline Very intoxicated & 10.4 & 5.6 & 9.1 \\
\hline Causal attribution of event to alcohol use among 6-hour drinkers & 78.1 & 47.5 & $69.1^{\star \star \star}$ \\
\hline \multicolumn{4}{|l|}{ Drinking pattern among current drinkers } \\
\hline Non-heavy drinking (no 5+ occasions) & 15.7 & 8.2 & $14.4^{\star * *}$ \\
\hline Occasional heavy drinking $(5+$ occasions $<$ weekly) & 52.2 & 79.5 & 56.9 \\
\hline Frequent heavy drinking ( $5+$ occasions $\geq$ weekly) & 32.2 & 12.3 & 28.7 \\
\hline \multicolumn{4}{|l|}{ Drug use } \\
\hline Positive saliva test, any drug $\mathrm{g}^{\mathrm{b}, \mathrm{c}}$ & 17.9 & 9.6 & $14.3^{\star \star \star}$ \\
\hline \multicolumn{4}{|l|}{ Positive saliva test, by type } \\
\hline Cannabis & 15.7 & 6.6 & $11.8^{\star \star \star}$ \\
\hline Amphetamine & 0.6 & 0.0 & 0.4 \\
\hline Cocaine & 3.2 & 3.8 & 3.5 \\
\hline Methamphetamine & 0.2 & 0.0 & 0.1 \\
\hline Opiates & 2.1 & 0.3 & $1.3^{*}$ \\
\hline Phencyclidine & 0.0 & 0.0 & 0.0 \\
\hline Any self-reported drug use within 6 hours prior to injury & 4.0 & 2.8 & 3.5 \\
\hline Self-reported cannabis use within 6 hours prior to injury & 2.8 & 2.1 & 2.5 \\
\hline \multicolumn{4}{|l|}{ Number of joints/pipes among 6-hour cannabis users } \\
\hline One or more puffs of joint/pipe & 64.3 & 57.1 & 62.0 \\
\hline Almost 1 joint/pipe & 14.3 & 28.6 & 19.0 \\
\hline Almost 2 joints/pipes & 21.4 & 14.3 & 19.0 \\
\hline \multicolumn{4}{|c|}{ Feeling impaired at the time among those using any drugs within 6 hours prior to injury } \\
\hline Not impaired & 25.0 & 75.0 & 41.7 \\
\hline A little impaired & 37.5 & 25.0 & 33.3 \\
\hline Moderately impaired & 25.0 & 0.0 & 16.7 \\
\hline Severely impaired & 12.5 & 0.0 & 8.3 \\
\hline Causal attribution of event to drug use among 6-hour users & 62.5 & 75.0 & 66.7 \\
\hline \multicolumn{4}{|l|}{ Frequency of cannabis use among current users } \\
\hline$<$ weekly & 36.4 & 85.7 & $55.6^{* *}$ \\
\hline zweekly & 63.6 & 14.3 & 44.4 \\
\hline
\end{tabular}

BAC, blood alcohol concentration estimate

Among the $97 \%$ who were breathalyzed, and includes the $1 \%$ who reported drinking after the injury event.

Among the $90 \%$ who were saliva tested, and includes the $0.07 \%$ who reported using drugs after the injury event.

cPercentage calculated including the $7.3 \%-8.5 \%$ of saliva tests that were indeterminate.

Source: Prepared by the authors from the study results

significantly more likely to report more frequent use ( $\geq$ weekly) $(63.6 \%)$ than those in Peru $(14.3 \%)(p<0.01)$.

As shown in Table 3a, $19.3 \%$ of drivers reported drinking within six hours prior to the RTI, compared with $12.5 \%$ of passengers and $10.3 \%$ of pedestrians. Likelihood of RTI was elevated over two and a half times $(\mathrm{OR}=2.60, p<0.001)$ from drinking, and was significant for drivers $(\mathrm{OR}=2.57, p<0.001)$ and for passengers $(\mathrm{OR}=2.77, p<0.05)$, but was not significant for pedestrians $(\mathrm{OR}=2.54)$, possibly due to the smaller number of pedestrians. 
TABLE 3a. Odds ratios for any alcohol use on risk of a road traffic injury

\begin{tabular}{|c|c|c|c|}
\hline & $N^{a}$ & $\mathrm{OR}$ & $95 \% \mathrm{Cl}$ \\
\hline All RTIs combined & 3298 & 2.60 & $(1.85,3.76)^{\star \star *}$ \\
\hline Drivers & 2346 & 2.57 & $(1.77,3.90)^{\star \star \star}$ \\
\hline Passengers & 522 & 2.77 & $(1.07,7.18)^{\star}$ \\
\hline Pedestrians & 430 & 2.54 & $(0.62,10.35)$ \\
\hline
\end{tabular}

$\mathrm{OR}$, odds ratio; $\mathrm{Cl}$, confidence interval; $\mathrm{RTI}$, road traffic injury

${ }^{a} N$ s are number of valid person-periods used for $1: \mathrm{m}$ matching (1 injury period vs. $m=1-7$ control periods) in the case-crossover analysis.

Source: Prepared by the authors from the study results

TABLE 3b. Odds ratios for volume levels on risk of a road traffic injury

\begin{tabular}{|c|c|c|c|}
\hline & $N^{\mathrm{a}}$ & $\mathrm{OR}$ & $95 \% \mathrm{Cl}$ \\
\hline $\begin{array}{l}\text { All RTIs combined (ref. no } \\
\text { alcohol) }\end{array}$ & 3298 & & \\
\hline $0.1-3.0$ drinks & & 3.76 & $(2.15,6.58)^{\star \star \star}$ \\
\hline $3.1-8.0$ drinks & & 10.33 & $(4.51,23.66)^{\star * *}$ \\
\hline$>8.0$ drinks & & 6.69 & $(3.52,12.73)^{\star \star *}$ \\
\hline Drivers (ref. no alcohol) & 2346 & & \\
\hline $0.1-3.0$ drinks & & 3.77 & $(2.08,6.83)^{\star \star \star}$ \\
\hline $3.1-8.0$ drinks & & 10.14 & $(3.98,25.85)^{\star \star \star}$ \\
\hline$>8.0$ drinks & & 7.39 & $(3.61,15.13)^{\star * *}$ \\
\hline Passengers (ref. no alcohol) & 522 & & \\
\hline $0.1-3.0$ drinks & & 4.13 & $(0.68,25.07)$ \\
\hline $3.1-8.0$ drinks & & $N A^{b}$ & \\
\hline$>8.0$ drinks & & 5.41 & $(0.80,36.57)$ \\
\hline Pedestrians (ref. no alcohol) & 430 & & \\
\hline $0.1-3.0$ drinks & & NA & \\
\hline $3.1-8.0$ drinks & & 4.48 & $(0.48,42.01)$ \\
\hline$>8.0$ drinks & & 2.27 & $(0.19,26.55)$ \\
\hline
\end{tabular}

OR, odds ratio; $\mathrm{Cl}$, confidence interval; RTI, road traffic injury

a Ns are number of valid person-periods used for 1:7 matching (1 injury period vs. 1-7 control periods) in the case-crossover analysis.

${ }^{b} \mathrm{NA}$, not available: $\mathrm{OR}$ cannot be generated because of empty cell

Source: Prepared by the authors from the study results

While risk of RTI was significant $(p<0.001)$ at all levels of consumption, and almost four times greater $(\mathrm{OR}=3.76)$ for up to three drinks, risk was over 10 times greater $(\mathrm{OR}=10.33)$ for $3-8$ drinks prior to injury (Table $3 b$ ). Risk fell at over eight drinks (OR $=6.69$ ). Few patients reported drinking $3-8$ drinks in the control periods (possibly reflecting the drinking pattern in these countries) which inflated the OR for this level of drinking. Findings were similar for drivers, but the fewer number of passengers and pedestrians precluded analysis in some drinking categories.

As shown in Table 4,3.7\% of drivers reported using cannabis within six hours prior to the RTI, compared with $3 \%$ of passengers and $3.5 \%$ of pedestrians. Likelihood of RTI was over three times greater $(\mathrm{OR}=3.17)$ from cannabis use, and over four times greater $(\mathrm{OR}=4.23)$ for drivers $(p<0.05)$. Risk was not significant for either passengers or pedestrians. To test whether risk from cannabis use changed after controlling for alcohol volume, both cannabis use and alcohol volume were entered into the equation. ORs from cannabis use dropped to 2.12 for
TABLE 4. Odds ratios for any cannabis use on risk of a road traffic injury

\begin{tabular}{lccc} 
& $N^{\mathrm{a}}$ & OR & $95 \% \mathrm{Cl}$ \\
All RTIs combined & 3298 & 3.17 & $(1.15,8.74)^{*}$ \\
Drivers & 2346 & 4.23 & $(1.32,13.57)^{*}$ \\
Passengers & 522 & 0.49 & $(0.02,13.38)$ \\
Pedestrians & 430 & 2.00 & $(0.13,29.95)$ \\
\hline OR, odds ratio; Cl, confidence interval; RTI, road traffic injury & & \\
a $N$ are number of valid person-periods used for 1:m matching (1 injury period vs. $m=1-7$ control periods) in the \\
case-crossover analysis. \\
* $p<0.05$ \\
Source: Prepared by the authors from the study results
\end{tabular}

TABLE 5. Odds ratios for alcohol and cannabis combined use on risk of a road traffic injury

\begin{tabular}{|c|c|c|c|}
\hline & $N^{\mathrm{a}}$ & $\mathrm{OR}$ & $95 \% \mathrm{Cl}$ \\
\hline All RTIs combined & 3298 & & \\
\hline - Alcohol only & & 2.41 & $(1.68,3.47)^{\star \star *}$ \\
\hline - Cannabis only & & 1.16 & $(0.26,5.16)$ \\
\hline - Both alcohol and cannabis & & 7.85 & $(2.24,27.57)^{\star \star}$ \\
\hline Drivers & 2346 & & \\
\hline - Alcohol only & & 2.46 & $(1.64,3.69)^{\star \star \star}$ \\
\hline - Cannabis only & & 3.34 & $(0.70,15.85)$ \\
\hline - Both alcohol and cannabis & & 6.89 & $(1.65,28.73)^{\star \star}$ \\
\hline Passengers & 522 & & \\
\hline - Alcohol only & & 2.52 & $(0.95,6.71)^{c}$ \\
\hline - Cannabis only & & $N A^{b}$ & \\
\hline - Both alcohol and cannabis & & $N A^{b}$ & \\
\hline Pedestrians & 430 & & \\
\hline - Alcohol only & & 1.83 & $(0.39,8.62)$ \\
\hline - Cannabis only & & $N A^{b}$ & \\
\hline - Both alcohol and cannabis & & $N A^{b}$ & \\
\hline \multicolumn{4}{|c|}{ 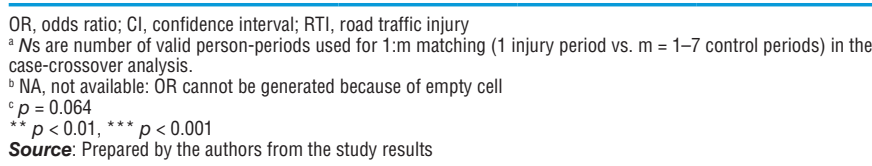 } \\
\hline
\end{tabular}

the total sample and 2.76 for drivers, and neither effect estimate was significant (not shown).

Patients who reported using alcohol may also have been using other drugs including cannabis, while those reporting cannabis use may also have been using other drugs including alcohol. As seen in Table 5, for all RTI types, alcohol use (OR $=2.41, p<0.001)$ and combined use with cannabis $(\mathrm{OR}=7.85$, $p<0.01)$ were significantly predictive of RTI, while cannabis use, alone, was not. Risk of RTI was over three times greater for combined use of alcohol and cannabis than from use of alcohol alone, reaching almost eight-fold. However, neither additive nor multiplicative interaction was found significant (RERI = 5.27, $p=0.284$; multiplicative interaction $\mathrm{OR}=2.80, p=0.260$ ). For drivers, both alcohol use $(\mathrm{OR}=2.46, p<0.001)$ and combined use with cannabis (OR $=6.89, p<0.01$ ) were significant predictors of RTI (but not cannabis use alone), with combined use over two and a half times more risky than alcohol use alone. Again, no significant interaction was observed for drivers. Due 
to relatively small numbers, risk estimates could not be produced for passengers or pedestrians for cannabis alone or for cannabis combined with alcohol. For alcohol alone, however, risk was marginally significant $(p=0.064)$ for passengers, but not for pedestrians.

\section{DISCUSSION}

Risk of RTI was significant for alcohol use (but not cannabis) and was greater for alcohol combined with cannabis, although a significant interaction was not observed. Risk for alcohol use was lower ( $\mathrm{OR}=2.6$ vs. 5.0 ) than that found in an earlier study of RTI in this region (7). Risk of RTI was primarily among drivers. Interestingly, passengers had a greater risk of RTI from alcohol use than drivers, but not when alcohol was considered alone, suggesting that many of these passengers may also have been using cannabis or other drugs along with alcohol prior to injury, while drivers may have been less likely to combine drugs. Drivers using cannabis were at significantly increased risk of RTI, but when risk for those using cannabis alone was examined this risk was not significant. Prior research has found that a larger number of drinks is reported in the six hours prior to injury among those also using other drugs during this same time, than among those using only alcohol (26). When alcohol volume was controlled, the ORs for risk from cannabis use dropped to insignificance. These data highlight the importance of considering multiple drug use in risk of RTI. This is the first research reported that has disaggregated risk of RTI from alcohol combined with cannabis for drivers, passengers, and pedestrians. The added risk for drivers from alcohol combined with cannabis compared with either substance alone is highly important for prevention and intervention efforts.

A dose-response relationship of alcohol and risk of RTI was apparent, but the middle dose category may have been inflated due to small numbers of patients reporting this level during the control periods. This may reflect the typical drinking patterns in these countries, where individuals tend to drink at either a lower level of consumption or a high level, with fewer reporting drinking between these two extremes. The number of passengers and pedestrians was too small for analysis in all three dose-response categories.

Large variations in demographic and substance use characteristics were found between the two sites. The vast majority of patients in the Dominican Republic were injured in an event involving a motorcycle/scooter but only 20\% reported helmet use, while slightly more than half of those in Peru were injured in events involving these two-wheeled vehicles (as well as bicycles), but $40 \%$ reported helmet use. A little over $10 \%$ of those in the Dominican Republic were injured in events involving a car, and less than half reported seatbelt use, while a third of those in Peru were so injured and only 10\% reported seatbelt use.

Similar percentages of patients in the Dominican Republic and Peru were positive on the breathalyzer, but those in Peru were again only half as likely to report drinking in the six hours prior to injury compared with those in the Dominican Republic. While those in the Dominican Republic were almost twice as likely to be drug positive as those in Peru, and over twice as likely to be positive for cannabis, small percentages in both sites reported drug use within six hours prior to injury. It is possible that the saliva screening test covered a much broader period of time than the six-hour period preceding the injury.
Among those drinking prior to injury, patients in the Dominican Republic were more likely to attribute a causal association of RTI with their drinking than those in Peru. In both sites, those believing they were intoxicated were more likely to report a causal association than those not feeling intoxicated, suggesting that these patients were aware of their risky drinking habits. Those in the Dominican Republic were also more likely to report frequent heavy drinking compared with those in Peru. Cultural discomfort to disclose use of alcohol in Peru may have led to under-reporting of causal attribution, as well as under-reporting of usual use (27).

The number of patients reporting any drug use was small, rendering differences between the Dominican Republic and Peru not significant; however, it appears that those in the Dominican Republic may have been more likely to use drugs prior to the RTI and to report being impaired at the time, but less likely to attribute a causal association of the RTI with use. They were also significantly more likely to report usual cannabis use at greater frequency than those in Peru.

Limitations to this study include the relatively small number of passengers and pedestrians, which resulted in less definitive analysis of risk of injury from alcohol and cannabis for these two groups, especially in relation to a dose-response relationship for alcohol. Additionally, the study was limited to only one ED in each of the two countries, precluding generalization of findings beyond the individual ED in which the data were collected.

Nevertheless, given the proportion of patients reporting drinking prior to the RTI, the large number of drinks consumed, and the proportions reporting being intoxicated and attributing a causal association of their drinking with the event, these data suggest that alcohol, especially in combination with cannabis, contributes significantly to the burden of RTI. This is the first report of risk of RTI, separately for drivers, passengers, and pedestrians, which examines the contribution of alcohol and cannabis alone and in combination, and demonstrates the added risk for RTI of combined use, especially for drivers, while cannabis alone does not appear to pose a significant risk.

Differences found between the two countries underscore the need for data from similar studies on alcohol in combination with cannabis throughout the region for drivers, passengers, and pedestrians to determine, at the regional level, the risk of RTI from alcohol and drug use. Additional countries would also provide the necessary number of patients to analyze risk of injury more definitively from combined use of alcohol and cannabis and the dose-response risk of RTI, especially for passengers and pedestrians. These data also suggest that if saliva testing for substance use is implemented as a surveillance tool, confirmatory analyses would be required. Given the contribution of alcohol alone and in combination with cannabis to the burden of RTI found in this study, more stringent enforcement of alcohol and drug control policy related to driving is recommended. These data also highlight the need for educational and awareness campaigns aimed at increasing knowledge regarding the additional risk of combining alcohol with cannabis when driving, as well as the need for advocacy and enforcement of public policies focused on use of protective devices such as helmets and seat belts.

Author contributions. CJC and MGM conceived the original idea. CJC and JW trained and supervised data collection. HM 
and JB collected the data. JW, YY, and CJC analyzed the data. All authors interpreted the results. CJC and JW wrote the first draft. All authors reviewed and approved the final version.

\section{Conflict of interest. None declared.}

Funding. Supported by the Inter-American Development Bank, the Pan American Health Organization, and a grant from the U.S. National Institute on Alcohol Abuse and Alcoholism (5 R01 AA013750). Sponsors did not influence in any way the design, data collection, analysis, writing, or the decision to publish these results.

Disclaimer. Authors hold sole responsibility for the views expressed in the manuscript, which may not necessarily reflect the opinion or policy of the RPSP/PAJPH and/or PAHO.

\section{REFERENCES}

1. World Health Organization. Global Status Report on Road Safety 2018. Geneva: WHO; 2018.

2. United Nations Road Safety Collaboration. Global plan for the decade of action for road safety 2011-2020. Geneva: World Health Organization; 2011. Available from: http://www.who.int/roadsafety/decade_of_action/plan/plan_english.pdf

3. United Nations. Transforming our world: the 2030 agenda for sustainable development (A/RES/70/1). New York: United Nations; 2015. Available from: https://sustainabledevelopment.un.org/content/documents $/ 21252030 \% 20$ Agenda $\% 20$ for $\% 20$ Sustainable $\% 20$ Development\%20web.pdf

4. Monteiro MG. Alcohol and public health in the Americas: a case for action. Washington, DC: Pan American Health Organization; 2007. Available from: https:/ /iris.paho.org/handle/10665.2/2826

5. Pan American Health Organization. Regional Status Report on Alcohol and Health in the Americas. Washington, DC: PAHO; 2015. Available from: https:/ /iris.paho.org/handle/10665.2/7670

6. Cherpitel CJ, Borges G, Giesbrecht N, Monteiro M, Stockwell T, editors. Prevention of Alcohol-Related Injuries in the America: From evidence to policy action. Washington, DC: Pan American Health Organization; 2013. Available from: https://iris.paho.org/ handle/10665.2/6085

7. Borges G, Monteiro M, Cherpitel CJ, Orozco R, Ye Y, Poznyak V, et al. Alcohol and road traffic injuries in Latin America and the Caribbean: a case-crossover study. Alcohol Clin Exp Res. 2017 Oct;41(10):1731-7.

8. United Nations Office on Drugs and Crime. World Drug Report 2016. New York: United Nations; 2016.

9. Keyes KM, Brady JE, Li G. Effects of minimum legal drinking age on alcohol and marijuana use: evidence from toxicological testing data for fatally injured drivers aged 16 to 25 years. Inj Epidemiol. 2015 Jan;2(1):1.

10. Guttmannova K, Lee CM, Kilmer JR, Fleming CB, Rhew IC, Kosterman $\mathrm{R}$, et al. Impacts of changing marijuana policies on alcohol use in the United States. Alcohol Clin Exp Res. 2016 Jan;40(1):33-46.

11. Gjerde H, Strand MC, Mørland J. Driving under the influence of non-alcohol drugs - an update. Part I: Epidemiological studies. Forensic Sci Rev. 2015 Jul;27(2):89-113.

12. Compton RP, Berning A. Drug and alcohol crash risk (Traffic Safety Facts Research Note. DOT HS 812 117) [Internet]. Washington, DC: National Highway Traffic Safety Administration; 2015 [cited 2016 Mar 3]. Available from: https://www.nhtsa.gov/sites/nhtsa.dot. gov/files/812117-drug_and_alcohol_crash_risk.pdf

13. Li M-C, Brady JE, DiMaggio CJ, Lusardi AR, Tzong KY, Li G. Marijuana use and motor vehicle crashes. Epidemiol Rev. 2012 Jan;34(1):65-72.

14. Els C, Jackson TD, Tsuyuki RT, Aidoo H, Wyatt G, Sowah D, et al. Impact of cannabis use on road traffic collisions and safety at work: systematic review and meta-analysis. Can J Addict. 2019 Mar;10(1):8-15.

15. Brault M, Dussault C, Bouchard J, Lemire A-M. [abstract] The contribution of alcohol and other drugs among fatally injured drivers in Quebec: final results. 17th International Conference on Alcohol, Drugs and Traffic Safety. Glasgow, United Kingdom, August 8-13, 2004.

16. Drummer $\mathrm{OH}$, Gerostamoulos J, Batziris $\mathrm{H}$, Chu M, Caplehorn J, Robertson MD, et al. The involvement of drugs in drivers of motor vehicles killed in Australian road traffic crashes. Accid Anal Prev. 2004 Mar;36(2):239-48.

17. Dubois S, Mullen N, Weaver B, Bédard M. The combined effects of alcohol and cannabis on driving: impact on crash risk. Forensic Sci Int. 2015 Mar;248:94-100.

18. Ronen A, Chassidim HS, Gershon P, Parmet Y, Rabinovich A, Bar-Hamburger R, et al. The effect of alcohol, THC and their combination on perceived effects, willingness to drive and performance of driving and non-driving tasks. Accid Anal Prev. 2010 Nov;42(6):1855-65.

19. Ramaekers JG, Robbe HWJ, O'Hanlon JF. Marijuana, alcohol and actual driving performance. Hum Psychopharmacol. 2000 Oct;15(7):551-8.

20. Romano E, Voas RB, Camp B. Cannabis and crash responsibility while driving below the alcohol per se legal limit. Accid Anal Prev. 2017 Nov;108:37-43.

21. Marillier M, Verstraete AG. Driving under the influence of drugs. WIREs Forensic Sci. 2019;1(3):e1326.

22. Cherpitel CJ, Witbrodt J, Korcha R, Ye Y, Kool B, Monteiro M. Multilevel analysis of alcohol-related injury, societal drinking pattern and alcohol control policy: Emergency department data from 28 countries. Addiction. 2018 Nov;113(11):2031-40.

23. Maclure M. The case-crossover design: a method for studying transient effect on the risk of acute events. Am J Epidemiol. 1991 Jan 15;133(2):144-53.

24. Mittleman MA, Maclure M, Tofler GH, Sherwood JB, Goldberg RJ, Muller JE. Triggering of acute myocardial infarction by heavy physical exertion. Protection against triggering by regular exertion. N Engl J Med. 1993 Dec 2;329(23):1677-83.

25. VanderWeele TJ, Knol MJ. A tutorial on interaction. Epidemiol Methods. 2014;3(1):33-72.

26. Cherpitel CJ, Martin G, Macdonald S, Brubacher JR, Stenstrom R. Alcohol and drug use as predictors of intentional injuries in two emergency departments in British Columbia. Am J Addict. 2013 Mar;22(2):87-92.

27. Málaga H, Ronceros J, Delgado L, Palza G. Restricciones de los horarios de expendio de licores en Lima Metropolitana y su efecto en las muertes violentas 2015-2017. Biotempo. 2019;16(2): 233-9.

Manuscript submitted on 13 August 2020. Revised version accepted for publication on 25 November 2020. 


\section{Traumatismos causados por el tránsito y consumo de sustancias psicoactivas en pacientes del departamento de urgencias en Perú y República Dominicana}

RESUMEN Objetivo. Presentar las características demográficas y de consumo de sustancias psicoactivas y el riesgo de traumatismos causados por el tránsito debidos al consumo de alcohol, cannabis y su consumo combinado en una muestra de pacientes del departamento de urgencias de dos países de América Latina y el Caribe.

Métodos. Se realizó un estudio transversal en que se entrevistaron pacientes de 18 años o más ingresados en las siguientes seis horas de haber recibido traumatismos causados por el tránsito en un departamento de urgencias en Lima (Perú) ( $n=431$ ) y en Santo Domingo (República Dominicana) $(n=501$ ). Se empleó el análisis de cruce de casos, basado en el consumo autoinformado con anterioridad a los traumatismos causados por el tránsito, para evaluar el riesgo por consumo de alcohol, cannabis y consumo combinado.

Resultados. En términos generales, $15,3 \%$ notificó consumo de alcohol con anterioridad al evento y 2,5\%, consumo de cannabis. Los conductores que consumieron alcohol únicamente tuvieron más del doble de probabilidades de sufrir traumatismos causados por el tránsito $(\mathrm{OR}=2,46, p<0,001)$ y casi ocho veces más probabilidades si consumieron tanto alcohol como cannabis ( $\mathrm{OR}=6,89, p<0,01)$, si bien el riesgo no fue tan elevado para el consumo único de cannabis. No se encontraron diferencias significativas en pasajeros o peatones.

Conclusiones. El riesgo de sufrir traumatismos causados por el tránsito para los conductores en estas dos muestras es significativamente más elevado por el consumo de alcohol y más aún por el consumo combinado con cannabis. Las diferencias entre ambos países ponen de manifiesto la necesidad de obtener datos similares sobre la región para determinar el riesgo de sufrir traumatismos causados por el tránsito debidos al consumo de sustancias psicoactivas, así como el riesgo para pasajeros y peatones. Los datos indican que el alcohol agrava significativamente la carga de los traumatismos causados por el tránsito, lo que exige un cumplimiento más estricto de las políticas de control del alcohol relacionadas con la conducción bajo los efectos del alcohol en la región.

Palabras clave

Accidentes de tránsito; seguridad; conducir bajo la influencia; consumo de bebidas alcohólicas; drogas ilícitas; servicio de urgencia en hospital; América Latina; región del Caribe. 


\section{Lesões por acidentes de trânsito e uso de substâncias químicas em pacientes que deram entrada no setor de emergência na República Dominicana e Peru}

RESUMO

Objetivo. Descrever as características demográficas e uso de substâncias químicas e o risco de lesões por acidentes de trânsito associados ao consumo de álcool, uso de cannabis (maconha) e uso combinado de álcool e cannabis em uma amostra de pacientes que deram entrada no setor de emergência em dois países da América Latina e no Caribe.

Métodos. Estudo transversal em que foram entrevistados pacientes maiores de 18 anos que deram entrada no setor de emergência no espaço de seis horas após sofrerem lesões por acidentes de trânsito em Santo Domingo, na República Dominicana $(n=501)$, e em Lima, Peru $(n=431)$. Foi realizada uma análise cruzada de casos com dados obtidos do autorrelato do uso de substâncias químicas anterior ao acidente de trânsito para avaliar o risco associado ao consumo de álcool, uso de cannabis e uso combinado.

Resultados. Dos pacientes entrevistados, 15,3\% relataram consumo de álcool e 2,5\% referiram uso de cannabis antes do acidente. Os condutores que fizeram uso de álcool tiveram uma chance duas vezes maior de ter lesões por acidente de trânsito $(\mathrm{OR}=2,46, p<0,001)$ e uma chance de cerca de oito vezes maior com o uso combinado de álcool e cannabis $(\mathrm{OR}=6,89, p<0,01)$. Porém, o risco não foi elevado com o uso somente de cannabis. Não foram observadas diferenças significativas no risco para passageiros ou pedestres.

Conclusões. Verificou-se que o risco de lesões por acidentes de trânsito para os condutores nas duas amostras estudadas foi significativamente elevado com o consumo de álcool e foi ainda maior com o uso combinado de álcool e cannabis. As diferenças entre os dois países reforçam a necessidade de dados semelhantes da Região para determinar o risco de lesões por acidentes de trânsito com o uso de substâncias químicas, inclusive para determinar o risco para passageiros e pedestres. Os dados indicam que o álcool contribui significativamente à carga de lesões por acidentes de trânsito requerendo o cumprimento mais rigoroso da política de controle do consumo de álcool associado à condução de veículos na Região.

Palavras-chave Acidentes de trânsito; segurança; dirigir sob a influência; consumo de bebidas alcoólicas; drogas ilícitas; serviço hospitalar de emergência; América Latina; região do Caribe. 